\title{
Molecular Autopsy for Sudden Cardiac Death
}

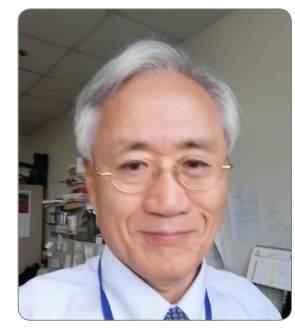

김성순

국군수도병원 내과 부정맥 클리닉

Sung Soon Kim, MD, PhD

Arrhythmia Service, Cardiology Division, Department of Medicine, The Armed Forces Capital Hospital, Bundang, Republic of Korea

\section{A Prospective Study of Sudden Cardiac Death among Children and Young Adults}

Bagnall RD, Weintraub RG, Ingles J, Duflou J, Yeates L, Lam L, Davis AM, Thompson T, Connell V, Wallace J, Naylor C, Crawford J, Love DR, Hallam L, White J, Lawrence C, Lynch M, Morgan N, James P, du Sart D, Puranik R, Langlois N, Vohra J, Whinship I, Atherton J, McGaughran J, Skinner JR, Semsarian C.

Received: March 2, 2017

Accepted: April 5, 2017

Correspondence: Sung Soon Kim, MD, PhD

Arrhythmia Service, Cardiology Division,

Department of Medicine, The Armed Forces

Capital Hospital, 81, Saemaeul-ro 177 beon-gil,

Bundang-gu, Seongnam-si, Gyeonggi-do 13574,

Republic of Korea

Tel: +82-31-725-6429 Fax: +82-2-393-2041

E-mail: kimss2866@yuhs.ac

\section{요약}

호주와 뉴질랜드에서 1-35세의 소아와 젊은 성인들을 대상으로 2010부터 2012년까지 돌연 심장사(sudden cardiac death)한 모든 증례들에 대하여 전향적으로 임상적, 역학적 및 부검 소견을 수집하였다. 독물학 검사와 조직검사를 포함한 부검 소견상 원인 질환이 밝혀지지 않은 증례에서는 최소 59 개의 심장 관련 유전자 변이(gene mutation)에 대하여 분석하였다.

총 490명의 돌연 심장사가 발생하여 연 발생률은 1-35세 인구 100,000 명당 1.3 명이었고, 남성이 $72 \%$ 였다. 연령별로는 31-35세 연령군에서 발생률(3.2 cases/100,000 persons per year)이 가장 높았고, 원인 질환이 밝혀지지 않은 돌연 심장사
발생률(0.8 cases/100,000 persons per year)은 16-20세 연령군에서 가장 높았다. 돌연 심장사의 밝혀진 원인 질환 으로는 관상동맥질환이 $24 \%$ 로 가장 많았고, 심근질환이 $16 \%$ 로 그 다음 빈도를 보였다. 그러나 전체적으로 보면 원인 불명의 돌연 심장사가 198 명(40\%)으로 가장 많았다. 연령별로는 31-35세 연령 군에서만 원인 질환으로 관상동맥 질환의 빈도가 가장 높았을 뿐, 나머지 연령군에서는 원인 불명이 최다였다. 부검 소견상 원인 불명으로 밝혀진 198명 중 113 명이 유전자 변이 검사를 받았다. 이 중 31 명 $(27 \%)$ 에서 임상적으로 심장과 연관된 유전자 변이가 밝혀졌다고 한다. 원인 불명의 돌연 심장사가 있었던 환자의 가족을 추적하는 과정에서 91 가족 중에서 12 가족(13\%)에서 유전과 관련된 channelopathy나 심근질환이 밝혀졌다. 이번 연구에서 
저자는 부검에 더하여 유전자 검사를 첨가함으로써 소아와 젊은 성인에서 원인불명 돌연 심장사의 원인을 밝히는 데 실제적인 도움이 될 것이라고 하였다.

\section{논평}

돌연 심장사는 모든 연령에 걸쳐서 시간과 장소를 가리지 않고 발생하며, 신속한 처치를 요한다는 특수성 때문에 원인 질환의 규명에 어려움이 있고, 또한 소생한 환자에서는 급사의 재발을 예방하고 치료하기 위하여서도 원인 질환의 규명은 매우 중요하다. 그러나 과거력이 전혀 없이 돌연히 급사한 사람은 부검을 하여도 원인 질환이 밝혀지지 않는 경우가 적지 않다. 지금까지 소아와 젊은 성인 연령군에서는 $1 / 3$ 정도가 원인 불명인 것으로 알려져 있고, 부검한 환자들을 대상으로 한 심장 관련 유전자 검사 $(\mathrm{KCNQ} 1, \mathrm{KCNH} 2$, $S C N 5 A, R Y R 2$ 유전자)에서도 대략 $1 / 3$ 정도에서 유전자 변이가 나타나는 것으로 알려져 있다. 2,3 그러나 지금까지의 연구들은 대부분 후향적이거나 일정 기간 축적된 증례들에 대한 연구이어서 실제 인구(population-based)에서 일어나는 급사의 실체를 반영하는 데는 제한적일 수밖에 없는 실정이다.

이번 연구에서 주목할 점은 호주와 뉴질랜드에서 1-35세 연령군의 모든 소아나 젊은 성인에서 발생한 돌연 심장사 증례 모두에 대하여 전향적인 연구를 수행하였다는 점과 부검 소견상 급사의 원인 질환이 규명되지 않은 198례(40\%) 중 113 례에 대하여 임상적으로 연관된 심장 유전자 59개에 대한 유전자 변이를 분석하였다는 점이다. 유전자 검사로 유관 심장유전자 변이가 31례(27.3\%)에서 있었는데, 유전자 검사를 받지 않았던 나머지 85명에서도 같은 빈도로 나타난다고 가정하여 추정한다면 부검 결과 원인 불명이면서 유전자 검사 역시 음성인 증례는 490명 중 144명(29.3\%)이라 할 수 있다. 즉, 두 나라의 1-35세 연령에 속하는 인구에서 발생하는 급사의 대략 $1 / 3$ 정도는 정밀한 부검과 지금까지 알려진 첨단 유전자 검사로도 원인이 밝혀지지 않는 소위 '특발성 돌연 심장사(idiopathic sudden cardiac death)'라 할 수 있다. 그리고 나머지 $10.7 \%$ 는 유전자 검사로 유전자 변이가 밝혀졌다. 즉, 두 나라의 1-35세 인구에서 발생하는 돌연 심장사 환자 10 명 중 1 명은 부검상 원인 불명이었지만 유전자 검사로 그 원인이 밝혀진 셈이다. 따라서 돌연 심장사의 원인 질환으로 원인 불명(29.3\%), 관상동맥질환(24\%) 그리고
유전성 심근질환(16\%)에 이어 유전자 검사를 이용한 분자부검 (molecular autopsy)이 제 4의 원인(부검 음성/유전자 검사 양성, $10.7 \%$ )으로 추가되었다는 점에서 의미가 있다고 할 수 있다.

실제로 생전에 전혀 과거 병력이 없었던 channelopathy 환자가 급사하였다고 가정할 때 급사 후 소생하였다면 심전도 소견 및 가족력 등을 바탕으로 channelopathy를 의심하게 되고, 유전자 검사로 확진 할 수도 있으나 그대로 사망하였다면 부검으로는 원인을 알 수가 없을 것이고, 유전자 검사만이 유전자 변이로 해당 channelopathy를 진단할 수 있을 것이다.

유전자 검사는 long QT syndrome (LQTS)에서 유전자 변이에 따라 LQTS1 (KCNQ1), LQTS2 (HERG), LQTS3 $(\mathrm{SCN} 5 \mathrm{~A})$ 로 분류가 되고 이에 따라 임상 양상이 다르며, 치료에 있어서도 베타차단제에 대한 반응이 다름이 밝혀지면서 소위 channelopathy 전반에 대하여 유전자 검사가 각광을 받게 되는 계기가 되었다고 할 수 있다. 비단 유전자 검사는 피해 환자의 진단뿐만 아니라 유전적 소인이 가족적으로 나타나는 점에서 증상이 없는 channelopathy 환자 가족의 급사의 위험도를 판별하는 데도 기여하고 있다. 본 연구에서도 원인 질환이 밝혀지지 않았던 돌연 심장사 가족들의 추적 관찰에서 $13 \%$ 에서 유전자 변이가 밝혀졌다는 사실이 이를 뒷받침하고 있다. 이제 돌연 심장사로 사망한 환자에서 원인 질환 규명에 부검과 함께 유전자 검사를 도입함으로써 소위 특발성 돌연 심장사-(idiopathic sudden cardiac)의 원인 질환 규명에 '분자부검(molecular autopsy)' 의 시대가 바야흐로 도래하는 것이 아닌가 기대된다.

\section{References}

1) Bagnall RD, Weintraub RG, Ingles J, Duflou J, Yeates L, Lam L, Davis AM, Thompson T, Connell V, Wallace J, Naylor C, Crawford J, Love DR, Hallam L, White J, Lawrence C, Lynch M, Morgan N, James P, du Sart D, Puranik R, Langlois N, Vohra J, Whinship I, Atherton J, McGaughran J, Skinner JR, Semsarian C. A prospective study of sudden cardiac death among children and young adults. $N$ Engl J Med. 2016;374:2441-2452.

2) Winkel BG, Holst AG, Theilade J, Kristensen IB, Thomsen JL, 
Ottesen GL, Bundgaard H, Svendsen JH, Haunsø S, Tfelt-Hansen

J. Nationwide study of sudden cardiac death in persons aged 1-35 years. Eur Heart J. 2011;32:983-990.
3) Tester DJ, Ackerman MJ. Postmortem long QT syndrome genetic testing for sudden unexplained death in the young. J Am Coll Cardiol. 2007;49:240-246. 